\title{
Immunocytochemical localization of binding 'sites' for LH and hCG in preimplantation mouse embryos
}

\author{
Jayasree SenGupta, P. D. Gupta*, S. K. Manchanda and \\ G. P. Talwar* \\ Departments of Physiology and *Biochemistry, All India Institute of Medical Sciences, \\ New Delhi-110016, India
}

\begin{abstract}
Summary. By using an immunoperoxidase indirect antibody method, mouse blastocysts were found to bind specifically hCG and ovine LH but not FSH or the $\beta$ unit of hCG. Brown peroxidase reaction products were present in the morula and increased with the formation of the blastocoele. The LH/hCG binding 'sites' may be related to the initiation of steroidogenesis in the embryo.
\end{abstract}

\section{Introduction}

Recent reports indicate the presence of an LH and hCG-like substance in mouse preimplantation embryos (Wiley, 1974) and in rabbit blastocoelic fluid obtained on Day 6 post coitum (Haour \& Saxena, 1974; Fujimoto, Euker, Riegle \& Dukelow, 1975). It is now well established that cell membrane receptors are necessary for the mechanism of action of the various polypeptide hormones. Our present study was therefore initiated to determine whether any gonadotrophin binding sites are present on the cells of mouse preimplantation embryos as a preliminary effort towards identifying a functional role of LH or hCG in the embryos during the period of implantation.

\section{Methods and Materials}

Randomly bred Swiss mice were mated and the day of finding a vaginal plug was designated as Day 1 of pregnancy. The 200 mice were killed on Day 4 at $08: 00 \mathrm{~h}$ and 14:00 h to recover morulae and early blastocysts, respectively, by flushing the reproductive tract with Hank's balanced salt solution (BSS), pH 7.4. The embryos were washed with BSS and at each stage were pooled and incubated in batches of 20 in Petri dishes in $0.1 \mathrm{ml}$ phosphate-buffered saline (PBS), pH 7.4, containing (i) $6 \mu \mathrm{g}$ ovine $\mathrm{LH}$ (NIH-LH-S18), (ii) 5 i.u. hCG (purified preparation $=10000$ i.u./mg protein, (iii) $5 \mu \mathrm{g} \beta$-hCG, or (iv) $6 \mu \mathrm{g}$ ovine FSH (NIH-FSH-S11). Incubations were carried out at $37^{\circ} \mathrm{C}$ for $60 \mathrm{~min}$. The embryos were then washed thrice with $15 \mathrm{ml} \mathrm{BSS}$ and incubated for $60 \mathrm{~min}$ at $37^{\circ} \mathrm{C}$ with antisera (raised in rabbits) to ovine LH or to hCG (Vaitukaitis, Robbins, Nieschlag \& Ross, 1971) diluted 1:100 in PBS. The groups of morulae and blastocysts incubated in $\beta$-hCG were exposed after a 15 -min wash in BSS to antiserum to $\beta$-hCG (Vaitukaitis et al., 1971), at 1:100 dilution in PBS, for 60 min at $37^{\circ} \mathrm{C}$. The embryos were then washed with three changes of BSS $(5 \mathrm{ml}$ each time) for $15 \mathrm{~min}$ and treated with monospecific sheep anti-rabbit immunoglobulins tagged with peroxidase (kindly provided by Dr S. Avrameas, Institut Pasteur, Paris) at 1:50 dilution in PBS for $30 \mathrm{~min}$. The peroxidase was localized by placing the embryos, after washing in BSS, in a freshly prepared solution of $0.05 \%$ diaminobenzidine (Sigma Chemical Co.) and $0.001 \% \mathrm{H}_{2} \mathrm{O}_{2}$ in $0.1 \mathrm{M}$-Tris- $\mathrm{HCl}$ buffer at $\mathrm{pH} 7.4$ for $10 \mathrm{~min}$ at room temperature (Graham \& Karnovsky, 1966; Avrameas, 1969). The embryos were finally washed in Tris- $\mathrm{HCl}$ buffer and mounted whole in a drop of glycerine on a glass slide for microscopic examination. Control assays were run concurrently: embryos at the same stage were incubated with normal rabbit serum at 1:100 dilution instead of the antigonadotrophin sera. The nonspecific peroxidase activity in the embryos was gauged by incubating embryos directly with antirabbit immunoglobulins (raised in sheep) conjugated with peroxidase at 1:50 dilution in PBS. In addition, embryos were incubated directly in diaminobenzidine $-\mathrm{H}_{2}^{m} \mathrm{O}_{2}^{\mathrm{i}}$ reagent for detection of endo- 
genous peroxidase activity in the embryonic cells. Incubation of morulae and blastocysts in all four hormones and in the three control assay media were repeated on different days at least 6 times.

\section{Results}

The presence of reaction products of peroxidase in embryos incubated with LH or hCG is shown in Plate 1. The ability to bind LH and hCG was evident at the morula stage (Pl. 1, Fig. 2) but was much more obvious at the blastocyst stage (Pl. 1, Fig. 1). The distribution and localization of the granules were similar after incubations with either hormone. The experiments were conducted with about 500 normal embryos, and the results were reproducible for the two embryonic stages, and with incubations in the hormones on different days.

It is unlikely that the LH and hCG binding 'sites' revealed by this immunoenzymatic technique represent non-specific adherence of the hormones. The embryos were washed several times after each incubation and the grains were always located at the periphery of the cells of the trophoblast and inner cell mass (Pl. 1, Fig. 3). Embryos incubated in normal rabbit serum before reaction with antirabbit immunoglobulins conjugated with peroxidase were devoid of activity (Pl. 1, Fig. 4). No reaction was seen when the embryos were incubated only with anti-rabbit immunoglobulins conjugated with peroxidase, indicating the specificity of the reaction products found in the embryos incubated in anti-LH or anti-hCG sera. Furthermore, the absence of any reaction products in embryos incubated in diaminobenzidine- $\mathrm{H}_{2} \mathrm{O}_{2}$ reagent alone confirmed that endogenous peroxidase activity was not being detected in the present assay system. Another argument in favour of the specificity of binding is furnished by the results of the incubations with $\beta$-hCG. The antibodies in the antiserum to $\beta-h C G$ detected $\beta$-hCG and hCG specifically and discriminated between ovine LH and hCG. The second step of the reaction with peroxidase-tagged antibodies showed that there was no fixation of $\beta-h C G$ on the embryos (Pl. 1, Fig. 5). The $\beta$-hCG used for these experiments was a well characterized and highly purified preparation in which the undissociated hCG was removed (Talwar et al., 1976). The specificity of the antiserum was confirmed by radioimmunoassay as described elsewhere (Salahuddin, Ramakrishnan, Dubey \& Talwar, 1976). The embryos incubated with FSH failed to show any peroxidase reaction, indicating the specificity of the binding 'sites' for LH and hCG molecules.

In additional experiments, mouse blastocysts were incubated directly in anti-hCG serum and then processed as described above in anti-rabbit immunoglobulins tagged with peroxidase and the diaminobenzidine- $\mathrm{H}_{2} \mathrm{O}_{2}$ reagent. All blastocysts showed faint brown deposits, suggesting the possibility of antigonadotrophin-reacting material in the embryonic cells.

\section{Discussion}

These observations show that hCG and ovine $\mathrm{LH}$ can bind to the mouse morula and blastocyst. These hormones, although not native to the species, are nevertheless biologically active in mice in that they induce ovulation and increase uterine weight. Treatment with antisera to LH and hCG can terminate pregnancy in mice (Moudgal, 1975). The biological implications of these findings are not

\section{EXPLANATION OF PLATE}

Fig. 1. A mouse blastocyst treated wth hCG, showing the reaction product along the cell boundaries of the trophoblast and inner cell mass. $\times 1300$.

Fig. 2. A morula treated with hCG, showing the weak reaction in the undifferentiated cells. $\times 1300$.

Fig. 3. Higher magnification of Fig. 1 showing the granular deposits (arrowed) in the cytoplasm and at cell boundaries. Note the absence of any grains on the zona pellucida (ZP) and in the perivitelline space (PVS). $\times 2800$.

Fig. 4. Blastocyst incubated in normal rabbit serum. There are no deposits in any of the cells. $\times 1300$.

Fig. 5. Blastocysts incubated in $\beta$-hCG. Note the absence of any reaction product in the cells. $\times 9100$. 
PLATE 1
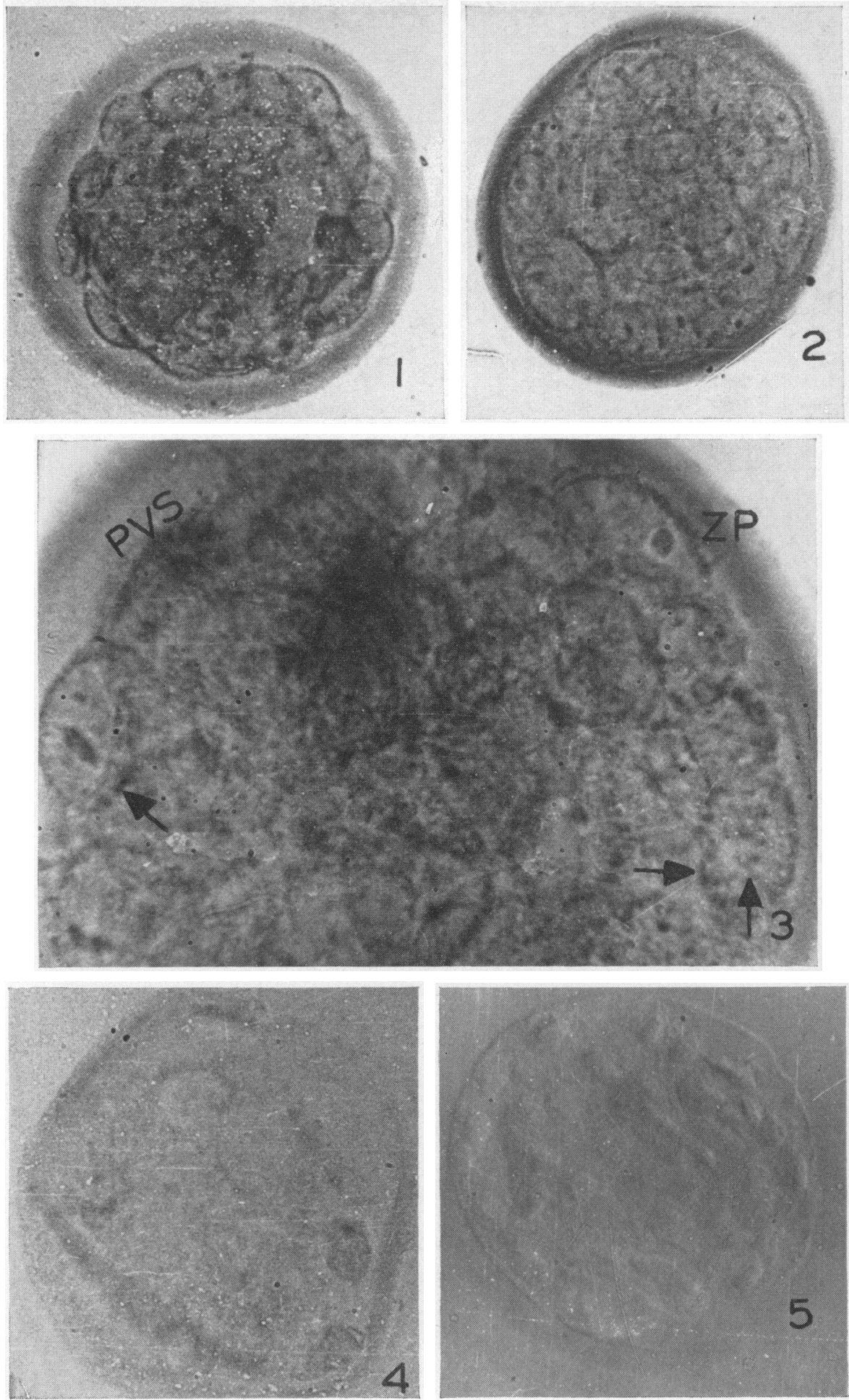

Downloaded from Bioscientifica.com at 04/26/2023 08:15:43AM 
clear. The presence of binding sites could make the blastocysts sensitive to endogenous pituitary gonadotrophins, and an $\mathrm{LH}$ coat around the blastocyst could provide some protection against immunological rejection of the conceptus (see Borland, Loke \& Wilson, 1975). The gonadotrophins could also stimulate discrete metabolic activities in the embryo, such as steroidogenesis, although direct evidence for this action is not yet available. Rodent morulae and blastocysts have, however, been shown to synthesize steroids (Dickmann, Dey \& SenGupta, 1976).

The work was supported by Grants from the World Health Organization and I.C.M.R., Government of India. The hCG and $\beta$-hCG were made available by the Population Council, New York, U.S.A.

\section{References}

AvRameas, S. (1969) Coupling of enzymes to proteins with glutaraldehyde use of the conjugate for the detection of antisera and antibodies. Immunochemistry 6, 43-52.

BORLAND, R., LOKE, Y.W. \& WiLsoN, D. (1975) Immunological privilege resulting from endocrine activity of trophoblast in vivo. In Immunology of Trophoblast, pp. 157-169. Eds R. G. Edwards, C. W. S. Howe \& M. H. Johnson. Cambridge University Press.

Dickmann, Z., Dey, S.K. \& SenGupta, J. (1976) A new concept: control of early pregnancy by steroid hormones originating in the preimplantation embryo. Vitams Horm. 34, 215-242.

Fujimoto, S., Euker, J.S., Riegle, G.D. \& Dukelow, W.R. (1975) On a substance cross-reacting with luteinizing hormone in the pre-implantation blastocyst fluid of the rabbit. Proc. Jap. Acad. 51, 123-125.

GrahaM, R.C. \& KaRnovsKy, M.J. (1966) The early stages of absorption of injected horseradish peroxidase in the proximal tubules of mouse kidney. $J$. Histochem. Cytochem. 14, 291-302.

HAOUR, F. \& SAXENA, B.B. (1974) Detection of a gonado- trophin in rabbit blastocyst. Science, N.Y. 185, 444 445.

Moudgal, N.R. (1975) Passive immunization with antigonadotropin antisera as a method of menstrual regulation in the primate. In Immunization with Hormones in Reproduction Research, pp. 233-237. Ed. E. Nieschlag. North Holland, Amsterdam.

Salahuddin, M., Ramakrishnan, S., Dubey, S.K. \& TAlWAR, G.P. (1976) Immunological reactivity of antibodies produced by Pr-B-hCG-TT with different hormones. Contraception 13, 163-170.

Talwar, G.P., Sharma, N.C., Dubey, S.K., SalahudDIN, M., Shastri, N. \& Ramakrishnan, S. (1976) Processing of the preparations of B-subunit of human chorionic gonadotropin for minimization of cross-reactivity with human luteinizing hormone. Contraception 13, 131-140.

VaItUkaitis, J.L., RobBins, J.B., Nieschlag, E. \& Ross, G.T. (1971) Specific antisera with small doses of immunogen. J. clin. Endocr. Metab. 33, 988-991.

WILEY, L.D. (1974) Presence of a gonadotrophin on the surface of preimplanted mouse embryos. Nature, Lond. 252, 715-716.

Received 6 July 1977 